\title{
VHF無線電話通信の内容から見たVTSの運用実態
}

\author{
瀬田 広明 ${ }^{1} \cdot$ 大田 大 $^{2} \cdot$ Cemil YURTOREN ${ }^{3} \cdot$ Y. Volkan AYDOGDU ${ }^{3}$
}

\section{A Study on Actual State of VTS from the Viewpoint of VHF Radio Communication}

\section{Hiroaki SETA, Hiroshi OTA, Cemil YURTOREN and Y. Volkan AYDOGDU}

\begin{abstract}
VTS centers are established adjacent to high-density marine traffic areas around the world, and operators carry out the safety management of marine traffic. The authors of this paper analyzed and compared the content of VHF radio communication from marine communication monitoring systems from VTS centers in Ise Bay and Istanbul.

In this paper, the movements of real communicative situations can be shown by the characteristics of sea areas, and the operation systems, which are managed by VTS centers.

As a result, communicative contents, which depend on the sea area's properties, and frequencies of communications, which were in proportion to the number of navigational vessels, are proved by this study.

Judging from the merits and demerits of operation systems, sector systems, which have been used at the Istanbul VTS center, can offer information smoothly, while the responsibilities and the load of VTS operators must have increased. On the other hand, the system used by Ise Bay VTS center can avoid dangerous situations in advance, while communication problems between operators are difficult to solve.
\end{abstract}

Keywords : marine traffic engineering, vessel traffic services, VHF radio communication キーワード：海上交通工学、VTS、VHF 無線電話通信

\section{1.はじめに}

1948 年にイギリスのリバプールにおいて海難事 故防止を目的として船舶航行支援（Vessel Traffic service：VTS）が世界で初めて実施され、その後、 ヨーロッパからアメリカ大陸に向けて普及し、1980 年代には世界各地へと広がり、海上交通の安全確保 に寄与している(1)。2010 年の STCW 条約マニラ改正 では、船長及び一等航海士の最低限の能力基準に VTS の利用に関する項目が追加された。併せて、VTS オペレータに対しても IMO/IALA ガイドラインに準 拠した知識、技能の習得と運用、技能認定等の条件 が追加された ${ }^{(2)}$ 。しかしながら、国や海域によって
操船環境や交通環境、VTS の運用体制などが異なる ため、オペレータが船舶に対して行う情報提供の時 期や頻度、それらの判断基準や具体の内容などにつ いては、各VTS センターやオペレータに委ねられて いる。

これまでにVHF 無線電話通信を用いた船舶間のコ ミュニケーションや航法との関係について調査され た研究例 ${ }^{(3)}(4)$ は幾つか存在するが、VTS センターの 運用体制について無線通信の視点から調查した例は そしい。そこで本研究では、VTS オペレータと利用 者間で行われる無線通信の内容を分析からVTS の運 用実態を明らかにすることを目的とする。そのため、 
伊勢湾海上交通センター（以下、伊勢湾 VTSC とす る。）とイスタンブル VTS センター（以下、イスタン ブル VTSC とする。）を調查対象として設定した。

なお、本研究は電波法第 59 条（秘密の保護）に 留意し、個々の船名等は明示せず、VTS 運用実態の 解析を目的に無線通信の記録及びAIS 情報を利用寸 ることとした。

\section{VTS（航行支援業務）}

VTS に関する国際ルールは、1985 年に IMO が制定 したガイドラインがその基盤となっており、現在は IM0 Resolution A. 852 (20)や IALA Recommendation V-103に依り運用されている。これらのルールには、 「VTS センターは、国家または国家に委託された施 設、合法的な権限のもと設立されなければならない」 と規定され、「管制範囲を明確に提示し、十分に訓練 された適切な資格を持つVTS オペレータが適切な指 示を送らなければならない」と定められており、そ の主たる業務は、

（1） Information Service（情報提供）：船舶航行情 報、港湾 - 航路情報、気象 - 海象情報の提供

（2）Traffic Organization Service（通航管理）: 航海計画および通航路に関する情報収集、船舶 の動静および速力の監視、航行規制や航行安全 情報の提供

(3) Navigation Assistance Service（航行援助）: 航行に関する意思決定を支援するための助言

とされている。また、VTS オペレータの助言につい て「船舶がとるべき針路又は機関操作のような詳細 な操船内容については乗船中の船長又は水先人の判 断に任せる。航海に係る船長責任を侵害しないよう、 また、船長と水先人の関係を妨害することのないよ う配慮されるべきである。」と記されている(5)。

一方、日本の VTS では、一部海域において海上交 通の輻輳状況や航法の特殊性等の理由により、操船 が著しく困難な状態に陥ることが想定されるような 場合に、航路外待機の指示や強潮流海域の速力制限 など、日本の国内法である海上交通安全法に基づい て航行支援が実施されている。

\section{1 VTS センターの現状比較}

地中海と黒海を繋ぐトルコ海峡（チャナッカレ海 峡、マルマラ海、イスタンブル海峡の総称）は、分 離通航方式 (Traffic Separation Scheme: TSS) が
設定され、 7 つのセクターに分割された海域を 2 つ のVTS センター (イスタンブル VTSC、チャナッカレ VTSC) により航行支援が実施されている。図 1 には、 トルコ海峡に設置されたVTS センターの位置と各セ クターの設定海域を示している。

表 1 は伊勢湾 VTSC とイスタンブル VTSC を比較し たものである。伊勢湾 VTSC では管轄海域を 2 名のオ ペレータで担当しており、互いに情報を共有しなが ら航行船舶に対して情報提供を行っている。一方の イスタンブルでは、管轄海域を 4 つに分割したセク ター方式が採用されている。1つのセクターを 1 名 のオペレータが担当し、業務中はセクター内の責任 及び権限はその VTS オペレータ個人に委衫られてい る。精神的な負担軽減や体調管理も含め、規則で十 分に休息を取ることを求めている。また、通航管理 のための船舶からの情報入手方法にも相違があり、 伊勢湾 VTSC では前日までに届け出る事前通報と指 定された通報ラインに達したときに行う位置通報の

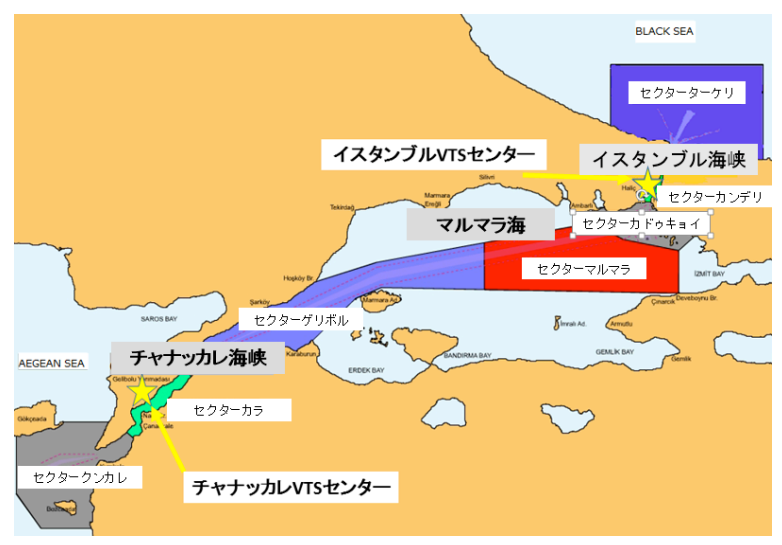

図 1 トルコ海峡と VTS の各セクター

表 1 伊勢湾とイスタンブルの VTSC の特徴

\begin{tabular}{|c|c|c|}
\hline & 伊勢湾 VTSC & イスタンブル VTSC \\
\hline $\begin{array}{l}\text { 管轄 } \\
\text { 海域 }\end{array}$ & $\begin{array}{c}\text { 伊良湖水道航路 } \\
\text { 及び } \\
\text { その周辺海域 }\end{array}$ & $\begin{array}{c}4 \text { セクター } \\
\text { (マルマラ、カドゥキョイ、 } \\
\text { カソデリ、ターケリ) }\end{array}$ \\
\hline $\begin{array}{l}\text { 管轄 } \\
\text { 面積 }\end{array}$ & 約 $500 \mathrm{~km}^{2}$ & 約 $1000 \mathrm{~km}^{2}$ \\
\hline $\begin{array}{l}\text { 当直 } \\
\text { 人数 }\end{array}$ & $\begin{array}{c}4 \sim 5 \text { 人 } \\
(2 \text { 人/全管制海域 })\end{array}$ & $\begin{array}{c}9 \text { 人 } \\
(1 \text { 人/セクター })\end{array}$ \\
\hline $\begin{array}{l}\text { 就労 } \\
\text { 時間 }\end{array}$ & $\begin{array}{c}2 \text { 直制 } \\
(9 \sim 16 \text { 時、 } 16 \sim 9 \text { 時 })\end{array}$ & $\begin{array}{c}12 \text { 時間勤務 } \\
\text { (6〜18 時、18〜 } 2 \text { 時) }\end{array}$ \\
\hline $\begin{array}{l}\text { 就労 } \\
\text { 資格 } \\
\end{array}$ & 海上保安官＋研修 & $\begin{array}{c}\text { 国際航路の船長経験 } \\
1 \text { 年以上十研修 }\end{array}$ \\
\hline $\begin{array}{l}\text { 位置 } \\
\text { 通報 } \\
\end{array}$ & $\begin{array}{l}\text { 事前通報と } \\
\text { 位置通報 } \\
\end{array}$ & TUBRAP と MARRAP \\
\hline $\begin{array}{l}\text { 通報 } \\
\text { 業務 } \\
\end{array}$ & $\begin{array}{c}\text { 海上法規に基づい } \\
\text { た情報提供 }\end{array}$ & $\begin{array}{c}\text { 状況判断から } \\
\text { 助言、許可 }\end{array}$ \\
\hline
\end{tabular}


2 つが規定され、後者を行うことで航行船舶の通航 順を定めて海上交通を管理している。一方、イスタ ンブルVTSC にも 2 種類の通報システムがあるが、そ れぞれ複数回の通報を要する。TUBRAP は事前通報に 該当するもので、トルコ海峡に入る前に行うSP1 レ ポートおよびSP2 レポート、イスタンブル海峡およ びチャナッカレ海峡への入峡時等に行うCall Point レポート、セクターを横断する際に通報する Position レポートがある。MARRAP はマルマラ海内で 行われるもので、TSS 入入る場合や TSS から出る際 に行われるものであるが、いずれも船舶を特定する ためものである。

\subsection{VTS センターの現地調查}

VTS センターの実態を把握するため、各 VTS セン ターを訪問しヒアリング調査を実施した。表 2 は、 VTS オペレータに対するヒアリング結果をまとめた ものである。

\section{3. 通信内容の分析}

イスタンブル VTSC と伊勢湾 VTSC では、管轄海域 の大きさ、当直人数や時間など、VTS の運用体制に 相違点があることを確認した。そこで、両 VTS セン ターの無線通信の運用実態を比較するため、VTS セ ンターと船舶との間で行われた無線通信の内容から 4 つの事項（使用言語の割合、通信時間、通信内容、 通信開始位置) について調查、検討を行った。表 3 には、通信内容を比較するための調査条件を示して いる。分析に必要となる情報は、鳥羽商船高専とイ スタンブル工科大学海事学部内に設置されている船 舶通信モニタリングシステム ${ }^{(6)}$ で取得しているもの を用いた。

伊勢湾ではVTS と船舶間の通信を行う際、13ch および $22 \mathrm{ch}$ を使用するため、これらを調査対象チャ ンネルとした。イスタンブル VTSC では、VHF のチャ ンネルが各セクターに 1 つずつ割りあてられており、 調查対象海域をセクターカドゥキョイと設定したた め、ここに割り当てられている $13 \mathrm{ch}$ を調查対象チャ ンネルとした。

\section{1 使用言語の割合}

図 2 は無線通信に用いられた言語の割合を海域別 に比較したものである。調查期間内に伊勢湾では 576 回、イスタンブル海峡では 2296 回の通信が行わ れていた。イスタンブルでは母国語より英語での通
表 2 ヒアリング結果

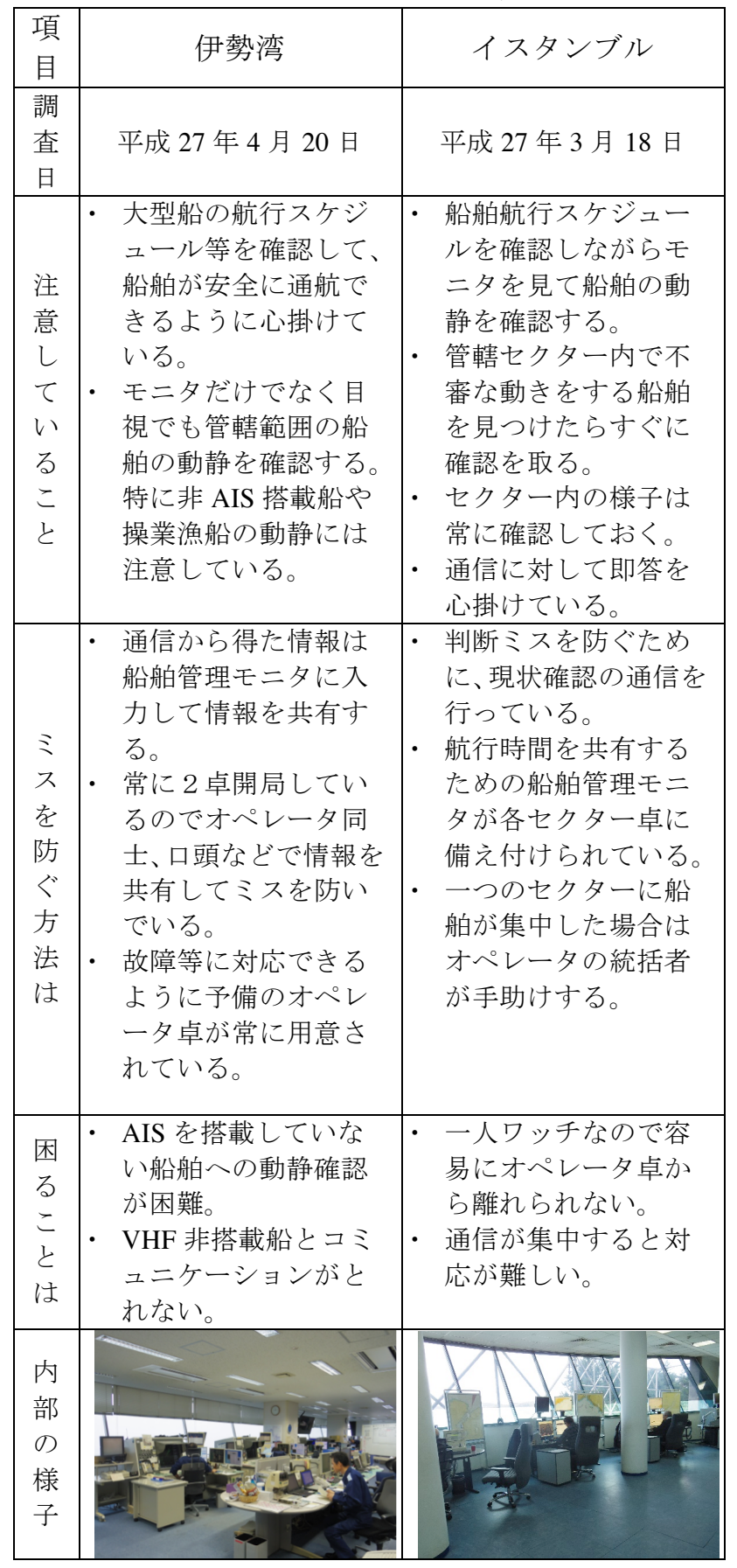

表 3 通信内容の取得方法

\begin{tabular}{|c|c|c|}
\hline & 伊勢湾 & イスタンブル \\
\hline $\begin{array}{l}\text { 録音 } \\
\text { 海域 }\end{array}$ & $\begin{array}{c}\text { 伊良湖水道及び } \\
\text { 周辺海域 }\end{array}$ & $\begin{array}{c}\text { イスタンブル海峡 } \\
\text { セクターカドゥキョイ }\end{array}$ \\
\hline $\begin{array}{l}\text { 録音 } \\
\mathrm{ch}\end{array}$ & $13,22 \mathrm{ch}$ & $13 \mathrm{ch}$ \\
\hline $\begin{array}{l}\text { 録音 } \\
\text { 期間 }\end{array}$ & $\begin{array}{c}2015 \text { 年 } 2 \text { 月 } 6 \text { 日 } 00 \text { 時 } \\
\text { ～} 015 \text { 年 } 2 \text { 月 } 8 \text { 日 } 00 \text { 時 }\end{array}$ & $\begin{array}{l}2015 \text { 年 } 9 \text { 月 } 1 \text { 日 } 00 \text { 時 } \\
\text { ～} 2015 \text { 年 } 9 \text { 月 } 3 \text { 日 } 00 \text { 時 }\end{array}$ \\
\hline $\begin{array}{l}\text { 録音 } \\
\text { 場所 }\end{array}$ & 鳥羽商船高専 & $\begin{array}{c}\text { イスタンブル工科大学 } \\
\text { 海事学部 }\end{array}$ \\
\hline $\begin{array}{l}\text { 空中 } \\
\text { 線高 }\end{array}$ & $30 \mathrm{~m}$ & $50 \mathrm{~m}$ \\
\hline
\end{tabular}


信が多いことがわかった。また、AIS 情報を用いて 当日通航した船舶の船籍について調查した結果、セ クターカドゥキョイを航行したトルコ籍船の割合は $32 \%$ あり、伊勢湾を航行した日本籍船の割合は $66 \%$ であった。使用言語の割合と母国籍船の割合の関係 から、水先人が乗船した場合には、VTS センターと の通信を母国語で行っていることが推察され、母国 語の使用割合が母国船籍の割合を上回ったと予想で きる。
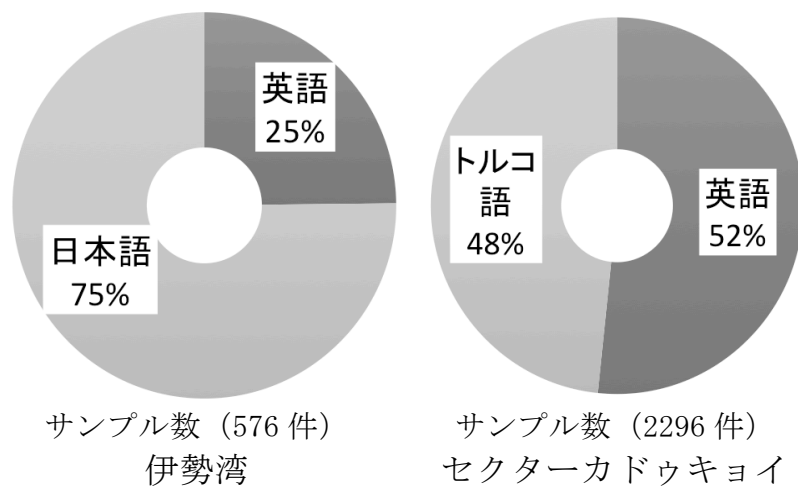

図 2 使用言語の割合

\section{2 通信時間と通信回数および通信内容}

表 4 はVTS センターと船舶との通信における 1 日 の平均通信回数と 1 回あたりの平均通信時間を示し ている。セクターカドゥキョイでは比較的短時間の 通信が数多く実施され、伊勢湾 VTSC では通信回数が 少ないものの 1 回あたりの平均通信時間が長くなっ ていることがわかった。通信内容から、幾つかの理 由が判明した。1つは情報の収集、提供方法が異な っている点である。伊勢湾 VTSC では位置通報を行っ た際に、海上交通に関連する情報（例えば、操業情 報など）を付加して操船者に提供していたためであ る。また、伊勢湾の位置通報では船名やコールサイ ン、行き先確認などを通報ラインで行うが、イスタ ンブル VTSC ではセクターマルマラもしくはセクタ ーターケリにおいて、TUBRAP の位置通報（SP2 レポ 一ト）を一度行うことで、イスタンブル VTSC が管轄 する 4 つのセクター内でデータの共有が成されてい る。しかし、VTS オペレータへの引継ぎや再確認の 意味を踏まえ、Position レポートやCall Pointレ ポートを行う必要があり、船名の呼出しと要件のみ の通信が多く、通信時間が短くなっていた。表 5 に はVTS センターと船舶間で行われた主な通信内容の 割合を示している。
表 4 海域別の通信回数と平均通信時間

\begin{tabular}{|c|c|c|}
\hline & 伊勢湾 & $\begin{array}{c}\text { セクター } \\
\text { カドゥキョイ }\end{array}$ \\
\hline 通信回数 & 192 回/日 & 765 回/日 \\
\hline 通信時間 & 約 60 秒/回 & 約 20 秒/回 \\
\hline
\end{tabular}

表 5 各海域における主な通信内容の割合

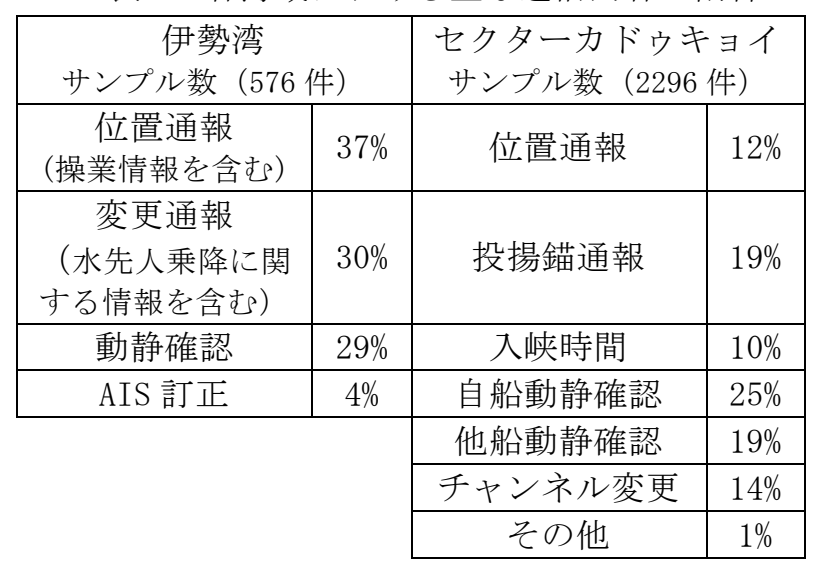

いずれも接近する船舶の情報や他船の動向など共 通する内容を確認することができた。しかし、イス タンブル VTSC では、入峡や追い越し可否の確認とい った自船動静確認や、通峡待ちの船舶が行う投揚錨 通報など、伊勢湾 VTSC では殆ど行われていない通航 管理の通信が行われていることもわかった。なお、 伊勢湾 VTSC では、操業情報を位置通報の通信時に併 せて行っていたため、表 5 の表記に位置通報（操業 情報含む）として処理している。

また、今回の調査において、伊勢湾 VTSC では操船 者から VTS オペレータに対して操船に関する判断を 委ねるような通信内容は確認できなかった。一方、 イスタンブル VTSC では、オペレータが船舶に対して 追い越しの許可や待機指示を与える通信を複数回確 認することができた。トルコ海峡内では原則追い越 し行為は禁止されているが、オペレータの許可があ れば追い越し可能となる。このような VTS オペレー タの判断により追い越しをかける船舶などが発生し た際、オペレータは当該船舶と見合い関係が悪くな るすべての船舶に対して他船の航行情報を提供して おり、表 4 においてイスタンブルVTSC との通信回数 が多くなっている一因であった。さらに、セクター カドゥキョイでは、基本的に $13 \mathrm{ch}$ のみで通信を行う ため、混信する場面があり、VTS オペレータが船舶 からの通信に円滑に対応できない時間帯があること を観取した。 


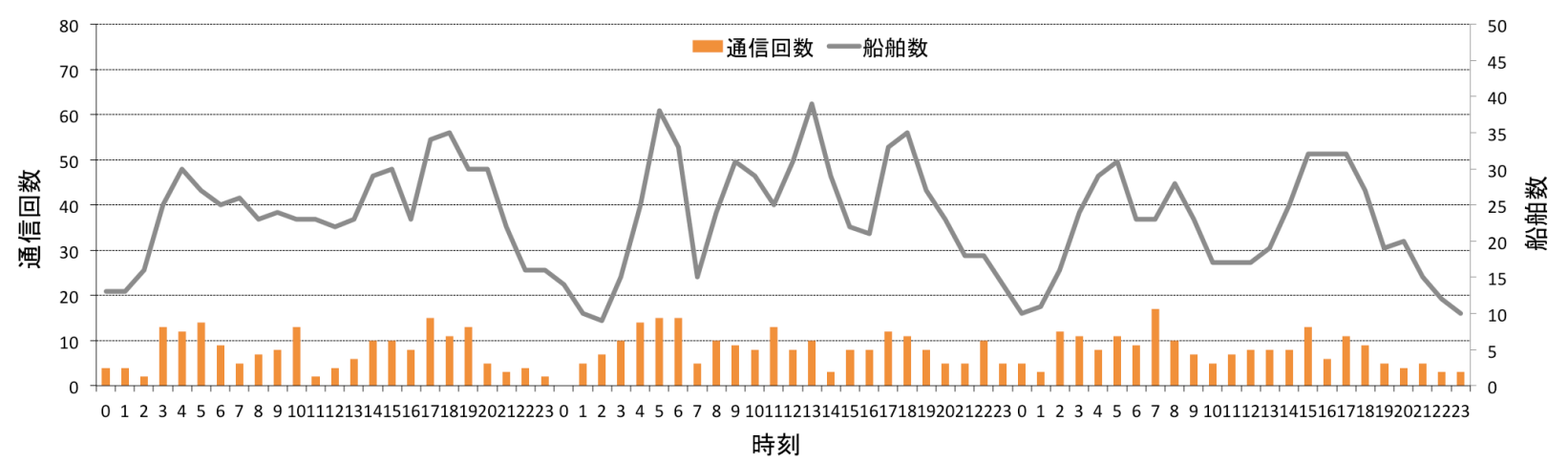

図 3 (a) 伊勢湾における通信回数と船舶隻数

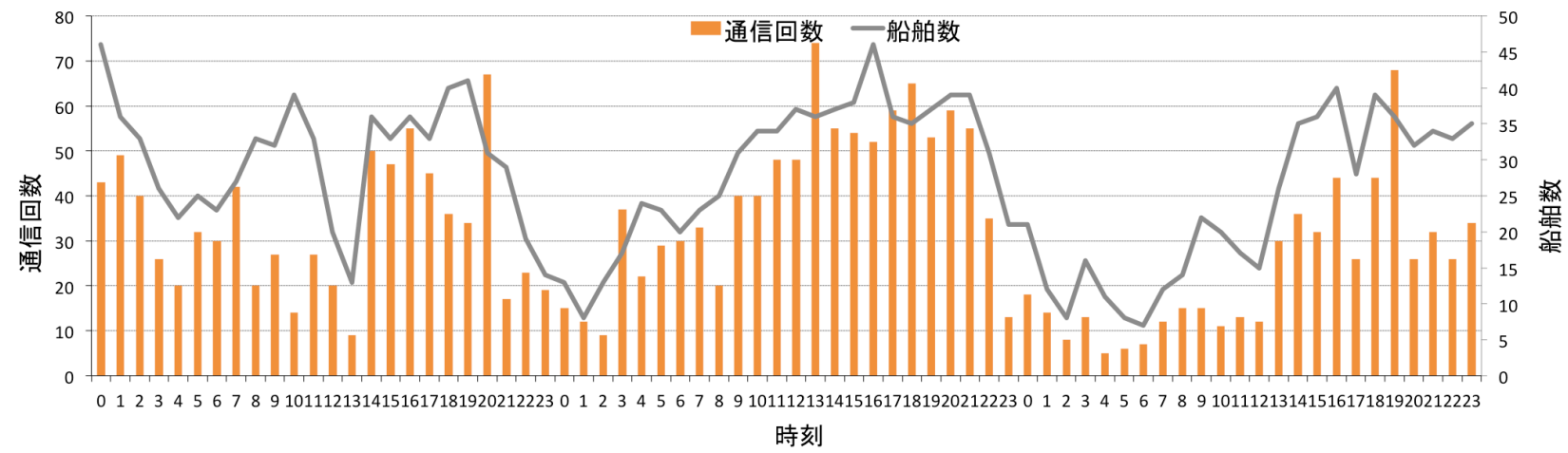

図 3 (b) セクターカドゥキョイにおける通信回数と船舶隻数

\section{3 時間帯別通信回数}

図 3 はVTS センターと船舶との間で行われた無線 通信の回数および航行隻数を時間別に表したもので ある。通信回数を棒グラフ、航行隻数を折れ線グラ フで示しており、通信回数は監視海域内での通信で あると認められたものをカウントしている。図 3 (a) より、伊勢湾では交通量が増加する早朝と夕方にか けて通信回数も増加していることがわかる。一方の 図 3(b)のイスタンブルでは、セクター内の船舶数と 通信回数との間に比例傾向があることが見て取れる。

図4は図3(a)および図3(b)の各時刻における通信 回数と船舶数プロットしたものであり、両海域とも それぞれ相関があることが窥えた。

\section{4 通信開始位置}

図 5 は伊勢湾およびイスタンブル海峡において、 VHF 無線電話による通信が開始された際の対象船舶 の位置と通信内容の種類を示している。

図 5 (a) は伊勢湾での状況を示しており、位置情報 を菱形、変更通報を星形、他船の動静に関する情報 を丸、水先人乗降に関する情報を三角の印で表して いる。ここでの通信は主要航路全域で行われている ことがわかる。また、セクターの設定が無いため、 VTS オペレータは広範囲を担当することが免れず、 複数のオペレータを配置し、連携しながら運用ミス

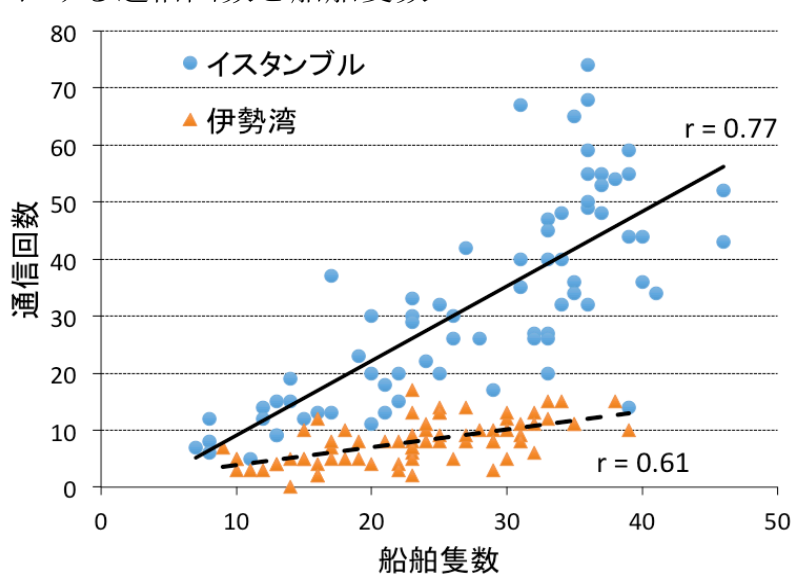

図 4 通信回数と船舶隻数の関係

が発生しないよう業務にあたる必要がある。しかし、 広範囲を管轄することで、航路出入り口付近のよう な危険海域で船舶が集中寸る状況に陥らないように 早い段階から運航調整を行うことが可能となり、結 果として海域全体の安全が確保されていると推し測 ることができる。

一方、図 5(b) はセクターカドゥキョイ周辺の状況 を示しており、位置情報を菱形、他船情報を丸、錨 泊情報を三角、入港情報を星型、そして、他チャン ネルへの変更通報を四角の印で表している。ここで の通信は、管轄対象海域内またはその近傍で行われ ていることがわかる。錨地付近では投揚錨通信や入 峡予定時刻に関する通信が多く、イスタンブル海峡 入り口付近および海峡の南口に位置するラウンドア 
バウト方式の航行分離帯付近では、入峡前の位置通 報や他船の動静に関寸る通信が多いことが確認でき た。また、ヒアリング結果からイスタンブルの VTS オペレータは、セクター内に存在する船舶へのサー ビスに専念し、当該海域を航行する船舶の動静を全 て把握することが求められる反面、オペレータに判 断を委ねられた場合には、瞬時に適切な判断を下寸 ことが示されており、このような通信が行われた際 には、周囲の船舶へのフォローも必要に応じて実施 していることが認められた。

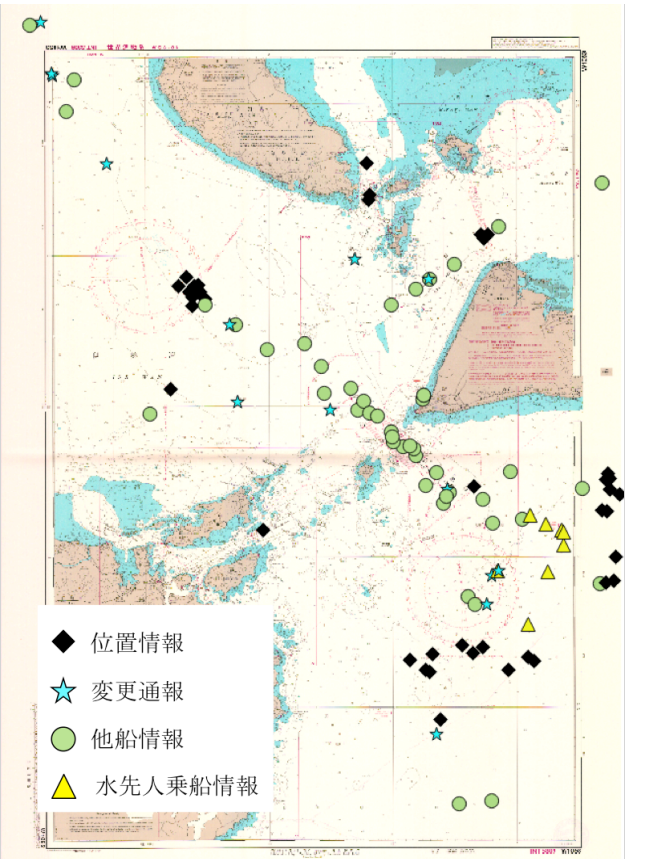

図 5 (a) 伊勢湾（海図W1051 使用）

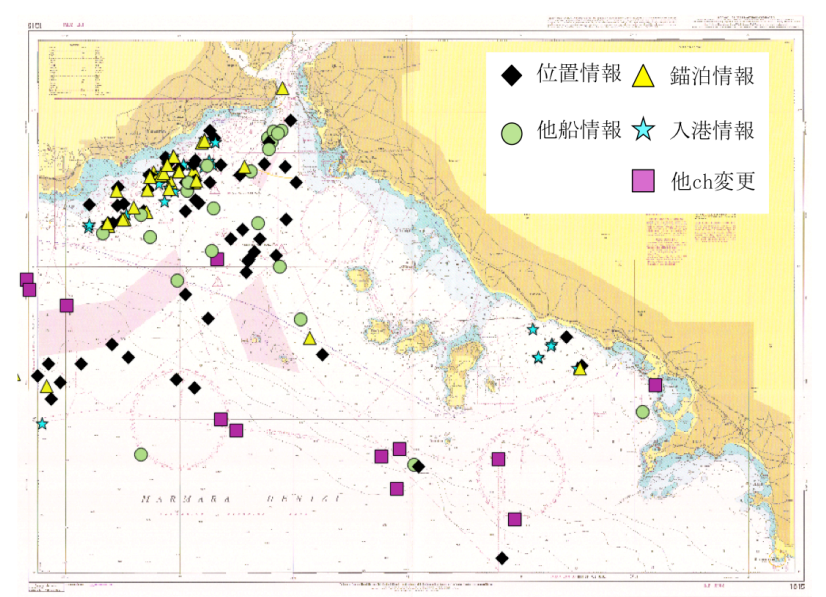

図 5(b) カドゥキョイ（英国版海図 1015 使用)

\section{5. むすび}

本論文では、船舶通信モニタリングシステムで取 得した情報を用いて、伊勢湾とイスタンブル海峡に
おけるVHF 無線電話通信の内容を調査し、VTS の現 状比較を行った。その結果、管轄する海域の特性や VTS センターの運用体制など、種々の要因により、 通信実態が異なることが確認できた。

分析結果について整理すると、海域特性の面から 見れば、双方の調查海域での共通事項は、狭水道の 入り口付近は位置通報や入航時間の確認、他船動静 情報に関する通信が増加している点と、通信回数と 通航隻数に相関がある点である。これらの共通点に 関しては経験則からある程度容易に想像することが できる。また、伊勢湾では伊良湖水道航路付近にお いて他船針路に関する情報提供の頻度が多くなされ ており、地形的制約により通峡可能時刻が決定づけ られるイスタンブル海峡では、時間調整のために行 っている錨泊に関する通信や通峡可能時間の確認な どに関する通信が際立っていた。また、イスタンブ ル VTSC 管轄内は TSS が設定されているため、漁船 は航路内を航行する船舶を避けなければならず、伊 勢湾のように漁船と一般航行船舶が航路内で競合す ることが無いという特徵がある。つまり、伊勢湾で は一般航行船舶と漁船との関係を視野に入れて対応 しなければならない。その意味において、この漁船 への対応という点において、イスタンブルと伊勢湾 のVTS オペレータの負担度が大きく異なるであろ うと言える。

他方の運用体制の面から見れば、セクター方式を 採用していない伊勢湾 VTSC では、おおよそ通信可能 範囲が管轄海域と捉えられ、この範囲でのサービス が求められることとなる。そのため、管轄海域が広 範囲になることから、VTS オペレータを複数人配置 し、情報を共有しながらヒューマンエラーを防止す るためのバックアップ体制がとられている。セクタ 一方式を取り入れているイスタンブル VTSC では、 VTS オペレータは、セクター内に存在する船舶への サービスに専念すれば良く、個々の船舶一の迅速な 対応が可能であるが、こちらはヒューマンエラーを 防止するために他船との通信を積極的に実施するよ う心掛けられていた。

また、VTS オペレータの視点から考察すると、VTS オペレータの能力を超える船舶を扱う状況下では、 複数のオペレータを配置することが望まれる。しか し、複数のオペレータが存在すれば意思決定の仕方 やその情報共有が煩雑となる久点が生じる。一方で、 1 人のオペレータのみで対応する場合の情報提供時 期や内容、その判断基準は個々のオペレータの主観 
的判断に委ねられている。万が一の失敗も許されな いVTS オペレータの精神的な負担軽減のためにも、 また、均一な安全レベルを担保するためにも、客観 的判断基準のもとで情報提供を行うことが可能な支 援システムの設計が必要といえる。

さらにVTS 利用者から見た場合、VTS センターと の通信は可能な限りの簡素化していることが望まれ る。その意味から、基本的にセクター毎に割り当て られたチャンネルのみを聴守し、同チャンネルで通 信することは合理的である。日本国内においては $16 \mathrm{ch}$ で通信相手を呼び出し、指定チャンネルへ移動 することが習慣付いているが、無線局運用規則では 海岸局の呼出は $16 \mathrm{ch}$ 以外でも可能とされている。日 本国内において過去の研究例 ${ }^{(6)}$ では $16 \mathrm{ch}$ 以外で直 接呼び出された例は見当たらなかった。合理的な運 用を行うという観点から見ると、セクター方式のよ うに直接指定チャンネルを用いて通信を始めること は好ましいが船舶が輻輳する時間帯等は通信の混信 が発生しやすいため注意が必要となる。

今後、VTS のあり方や運用基準などを策定する場 合には、VTS オペレータとVTS を利用する操船実務 者とが互いの共通認識の上に立ち、海上交通の円滑 さを損なわないことが重要であろう。

\section{謝辞}

本研究はJSPS 科研費 26350444 の助成を受けたも のです。

\section{参考文献}

（1）水城南海男 - 山内宏之・藤井弥平：世界のVTS に関する第 3 回調査結果とその解析, 日本航海 学会論文集, 第 121 号, pp. 91-99, 1989.9.

(2) IALA: IALA Recommendation V-103 on Standard for Training and Certification of VTS Personnel Edition2.1, p. 6, 2013. 12.

（3）脇田礼三・藤原紗衣子・藤本昌志 : 国際 VHF 無 線電話と航法の関係についての一考察, 日本航 海学会論文集, 第 131 巻, pp. 25-32, 2014. 12

（4）田崎祐一・鹿島英之・國枝佳明・竹本孝弘：輻 輳海域における国際 VHF を用いた船舶間コミュ ニケーションの特徵について, 日本航海学会論 文集, 第 133 巻, pp58-65, 2015. 12

(5) IM0: RESOLUTION A. 857 (20) adopted on 27

November 1997 Guidelines for vessel traffic service, p. 5, 1997. 12.
（6）瀬田広明 - 小野太津也 - 矢野雄基 - 鈴木治 : VHF 無線電話通信から見た伊勢湾の海上交通状況, 日本航海学会論文集, 第 121 号, pp. 55-61, 2009. 9. 